\title{
Оценка влияния срока производства прививок, длительности аэрации и стимуляторов роста на выход и качество привитых саженцев винограда
}

\author{
Виктор Павлович Клименко를 д-р с.-х. наук, зав. лабораторией генетики, биотехнологий селекции и размножения \\ винограда, vik_klim@rambler.ru; \\ Михаил Николаевич Борисенко ${ }^{1}$, д-р с.-х. наук, гл. науч. сотр. сектора питомниководства, borisenko_mn@mail.ru; \\ Юрий Александрович Белинский ${ }^{1}$, канд. с.-х. наук, зав. сектором питомниководства, belinskiy-50@mail.ru; \\ Олег Александрович Пелех ${ }^{2}$, агроном, peleholeg@mail.ru, \\ Артем Владимирович Райков³, управляющий, raykov_artem@mail.ru, \\ ${ }^{1}$ Федеральное Государственное бюджетное учреждение науки «Всероссийский национальный научно-исследовательский институт \\ виноградарства и виноделия «Магарач» РАН», Россия, Республика Крым, г. Ялта, ул. Кирова, 31, 298600 \\ 20бщество с ограниченной ответственностью «Завод марочных вин Коктебель», Россия, Республика Крым, г. Феодосия, пгт. Коктебель, ул. \\ Юнге, д.1, 298186; \\ ${ }^{3}$ Индивидуальный предприниматель «Зеленый континент», Россия, Республика Крым, Симферопольский район, с. Заречное, ул. \\ Предгорная, 32a, 297575
}

\begin{abstract}
Проведен эксперимент по исследованию приемов стратификации виноградных прививок «на воде» по разработанному плану полного трехфакторного эксперимента, всего 60 вариантов в трехкратной повторности. Выполнена прививка сорта Каберне-Совиньон на подвое Кобер 5ББ в условиях прививочной мастерской, всего 3960 шт. привитых черенков. Для анализа данных использовали трехфакторный дисперсионный анализ. Варианты срока производства прививок, стимуляторов, как и варианты аэрации, существенно отличались друг от друга по силе действия. Исследование позволяет признать с вероятностью не ниже 0,95, что влияние срока прививки и стимуляторов на выход привитых саженцев является достоверным. Результаты показывают отчетливое влияние факторов срока прививки и стимуляторов на выход саженцев винограда, которое в совокупности детерминирует более 3/4 изменчивости этого показателя. Исследование позволяет признать с вероятностью не ниже 0,95 , что влияние стимуляторов и аэрации, так же, как и их взаимодействия на вызревание побега является достоверным. Результаты показывают значительное влияние факторов стимуляторов и аэрации, и особенно взаимодействия стимуляторов и аэрации на вызревание побега, которые в совокупности детерминируют 86,5\% изменчивости этого показателя. Исследование позволяет признать с вероятностью не ниже 0,95, что влияние стимуляторов, так же, как и взаимодействия стимуляторов и аэрации, на толщину побега является достоверным. Результаты показывают существенное влияние фактора стимуляторов и взаимодействия стимуляторов и аэрации на толщину побега у основания, которые в совокупности детерминируют 60,5\% изменчивости этого показателя. Исследование позволяет признать с вероятностью не ниже 0,95, что влияние срока производства прививок, стимуляторов, аэрации так же, как и взаимодействия стимуляторов и аэрации, на количество пяточных корней является достоверным. Результаты показывают значительное влияние всех изучаемых факторов, а также взаимодействия стимуляторов и аэрации на количество пяточных корней, которые в совокупности детерминируют почти всю изменчивость этого показателя. Таким образом, влияние срока производства прививок, стимуляторов и длительности аэрации на качество привитых саженцев является достоверным.
\end{abstract}

Ключевые слова: виноград; прививка; саженцы; стратификация; срок прививки; аэрация; стимуляторы; дисперсионный анализ; взаимодействие факторов; модель.
O R I G I N A L A R T I C L E

Impact assessment of the grafting time, duration of aeration and growth stimulants on the output and quality of grafted grapevine seedlings

Viktor Pavlovich Klimenko', Mikhail Nikolayevich Borisenko ${ }^{1}$, Yury Aleksandrovich Belinsky1, Oleg

Alexandrovich Pelekh ${ }^{2}$, Artem Vladimirovich Raykov ${ }^{3}$ ${ }^{1}$ Federal State Budget Scientific Institution All-Russian National Research Institute of Viticulture and Winemaking "Magarach" of RAS 31 Kirova Str., 298600 Yalta, Republic of Crimea, Russian Federation 2000 Vintage Wines Plant Koktebel, Feodosiya, pgt. Koktebel, 1 Junge Str., 298186 Feodosiya, Republic of Crimea, Russian Federation ${ }^{3}$ Private entrepreneur Zelyonyi Kontinent, Predgornaya Str. 32a, 297575 Zarechnoe village, Simferopol region, Republic of Crimea, Russian Federation

An experiment was conducted to investigate methods for "in water" vine grafts stratification by a developed plan of a full three-factor experiment, a total of 60 variants in triplicate. The 'Cabernet-Sauvignon' cultivar was grafted onto 'Kober 5BB' rootstock in the conditions of a grafting shop, a total of 3960 pieces of grafted cuttings. A three-factor variance analysis was used to analyze the data. The grafting terms, use of stimulants, as well as aeration options differed significantly in terms of effect. The study confirms with a 0.95 certainty the impact of the grafting time and stimulants on the output of grafted cuttings. The results demonstrate a clear impact of such factors as grafting time and stimulants on the output of grapevine seedlings, which cumulatively determine over $3 / 4$ of the variability of the indicator. The study confirms with a 0.95 certainty the impact of stimulants and aeration, along with their interactive effect on shoot lignification. The results demonstrate a significant influence of such factors as stimulants and aeration, and in particular the interaction between stimulants and aeration on shoot lignification, which cumulatively determine $86.5 \%$ of the variability of the indicator. The study confirms with 0.95 reliability the impact of stimulants, and the interaction between stimulants and aeration on shoot thickness. The results demonstrate a significant impact of stimulants and the interaction of stimulants and aeration on shoot thickness at the base, which cumulatively determine $60.5 \%$ of the variability of the indicator. The study confirms with a 0.95 certainty the impact of the grafting time, stimulants, aeration, as well as interaction between stimulants and aeration on the number of base

\footnotetext{
Как цитировать эту статью: 86-91. DOI 10.35547/IM.2019.21.2.001

How to cite this article: DOI 10.35547/IM.2019.21.2.001

уДК: 634.8.037:631.53/.541.2:631.811.98

Поступила 16.11.2018

Принята к публикации 16.05.2019

(C) Авторы, 2019
}

Клименко В.П., Борисенко М.Н., Белинский Ю.А., Пелех О.А., Райков А.В. Оценка влияния срока производства прививок, длительности аэрации и стимуляторов роста на выход и качество привитых саженцев винограда // «Магарач». Виноградарство и виноделие, 2019; $21(2) ;$ С

Klimenko V.P., Borisenko M.N., Belinsky Yu.A., Pelekh O.A., Raykov A.V. Impact assessment of the grafting time, duration of aeration and growth stimulants on the output and quality of grafted grapevine seedlings. Magarach. Viticulture and Winemaking, 2019; 21(1); pp. 86-91 
roots. The results demonstrate a significant impact of all the studied factors, along with interaction between stimulants and aeration on the number of base roots, which cumulatively determine most of the variability of the indicator. Thus, the impact of the grafting time, stimulants and duration of aeration on the quality of grafted seedlings is well attested.

Key words: grapevine; graft; seedlings; stratification; grafting time; aeration; stimulants; variance analysis; factor interaction; model.

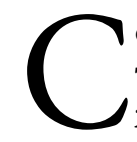

остояние вопроса. Совершенствование технологий производства привитых саженцев винограда явцяется непременным условием создания посадочного материала высоких категорий качества [1-9]. Аля разработки новых эффективных методов повышения выхода привитых саженцев винограда и укучшения их качества могут быть с успехом привцечены современные Аостижения физиомогии и биофизики растений [10-12]. ОАним из перспективных методов является регулирование роста и развития раневых тканей в процессе срастания компонентов привитых черенков (привоя и подвоя) на основе применения физиологически активных веществ [13-16]. Биологически активные вещества, в том числе фитогормоны, в современном сельском хозяйстве приобретают все бомьшее значение. При экзогенном введении в растение они вкАючаются в обмен веществ и активируют физиолого-биохимические процессы, повышая уровень жизнедеятемьности растений [17-19]. При использовании в винограАном питомниководстве регуляторы роста стимулируют корнеобразование, камиусогенез и сращивание компонентов прививки [20-23]. Применение стимуляторов роста растений обеспечивает более полную реализацию использования биологического потенциала винограда, позвомяет увемичить выход посадочного материала с еАиницы площаАи и значитемьно улучшить качество саженцев. Учитывая, что существующая технология не обеспечивает получение на завершающем этапе качественных привитых саженцев, целесообразно проведение многофакторного эксперимента.

Материалы и методы исследований. ПровеАен эксперимент по исследованию приемов стратификации виноградных прививок «на воде» [24], по разработанному пиану полного трехфакторного эксперимента, всего 60 вариантов в трехкратной повторности. Фактор «сроки прививки»: 2 варианта, середина и конец апреля. Фактор продомжительности аэрации базацьной части подвоя: 5 вариантов, 1-3-6-9-12 Аней. Фактор «стимуляторы роста»: 6 вариантов, вода (контроць), гетероауксин (этацон), Новосиц 0,01 \%, Новосиц 0,025 \%, NAGRO 0,01 \%, NAGRO 0,025\%.

Место проведения помевых опытов: г. Севастопомь, Нахимовский р-н (ООО «Качинский $+\gg)$. Выпомнена прививка сорта Каберне-Совиньон на подвое Кобер 5ББ в условиях прививочной мастерской, всего 3960 шт. привитых черенков. Сле-
Аует отметить, что в Аанном опыте испоцьзован подвой, полученный, озАоровленный и размноженный в Институте «Магарач», как сертифицированный материац высокой биологической категории [25]. Способ стратификации - открытый «на воде».

Рабочий раствор стимуляторов готовици в Аень обработки. Стандартный стимулятор гетероауксин соответствующей концентрации первоначацьно растворяии в 2-5 ми этицового спирта и Аоводими Ао нужного объема водой. Стимуляторы Новосим и биоэнергетик NAGRO растворями непосреАственно в воде Ао требуемой концентрации. Амя активизации камлусообразования привитых черенков место соприкосновения подвоя с привоем помещаци в раствор стимулятора на 2-3 секунды. Аля стимулирования корнеобразования у привитых черенков винограда базальную часть подвоя опускаци в рабочий раствор препарата на 20 секунА.

Проводими следующие учеты и наблюдения, которые характеризуют особенности получения качественных привитых саженцев: выход саженцев, \%; вызревание побега, \%; толщина побега у основания, мм; количество

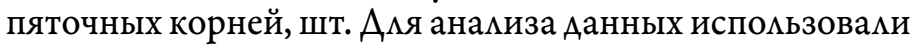
трехфакторный Аисперсионный анациз (пакет приклаАных программ STATISTICA).

Результаты и обсуждение. Из всех четырех версий взаимодействия трех факторов предварительная оценка массива Аанных Аля Аисперсионного анациза оставима только взаимодействие стимумяторов и аэрации. Исследование позволяет признать с вероятностью не ниже 0,95, что вАияние срока прививки, симуляторов и аэрации в целом на качество привитых саженцев явцяется Аостоверным (табл. 1). Варианты срока производства прививок и стимумяторов, как и варианты аэрации, су-

Таблица 1. Результаты статистической обработки данных по выходу и качеству привитых саженцев винограда, сортоподвойная комбинация Каберне-Совиньон × Кобер 5ББ, многомерные критерии значимости Уилкса

Table 1. The results of data statistical processing on the output and quality of grafted grapevine seedlings, cultivar-rootstock combination 'Cabernet Sauvignon' × 'Kober 5BB', Wilks' multidimensional significance criteria

\begin{tabular}{|c|c|c|c|c|c|}
\hline $\begin{array}{l}\text { Источник } \\
\text { изменчивости }\end{array}$ & $\begin{array}{l}\text { Значение } \\
\text { критерия }\end{array}$ & $\mathrm{F}$ & Эффект & Ошибка & $\mathrm{P}$ \\
\hline Срок прививки & 0,333933 & 12,965 & 4 & 26,0000 & 0,000006 \\
\hline Стимуляторы & 0,001261 & 28,267 & 20 & 87,1821 & 0,000000 \\
\hline Аэрация & 0,034941 & 9,998 & 16 & 80,0689 & 0,000000 \\
\hline $\begin{array}{l}\text { Взаимодействие } \\
\text { стимуляторов и } \\
\text { аэрации }\end{array}$ & 0,001074 & 6,112 & 80 & 104,9880 & 0,000000 \\
\hline
\end{tabular}


Таблица 2. Одномерные результаты трехфакторного дисперсионного анализа изменчивости выхода саженцев в зависимости от срока прививки, аэрации и стимуляторов

Table 2. One-dimensional results of a three-factor variance analysis of the output of seedlings variability subject to grafting time, aeration and stimulants

\begin{tabular}{|c|c|c|c|c|c|}
\hline $\begin{array}{l}\text { Источник изменчи- } \\
\text { вости }\end{array}$ & $\begin{array}{l}\text { Степень } \\
\text { свободы }\end{array}$ & $\begin{array}{l}\text { Сумма } \\
\text { квадра- } \\
\text { тов }\end{array}$ & $\begin{array}{l}\text { Срен- } \\
\text { ний } \\
\text { квадрат }\end{array}$ & $\mathrm{F}$ & $\mathrm{P}$ \\
\hline Срок прививки & 1 & 580,02 & 580,02 & 30,580 & 0,000006 \\
\hline Стимуляторы & 5 & 429,94 & 429,94 & 22,668 & 0,000000 \\
\hline Аэрация & 4 & 20,22 & 20,22 & 1,066 & 0,391106 \\
\hline $\begin{array}{l}\text { Взаимодействие сти- } \\
\text { муляторов и аэрации }\end{array}$ & 20 & 11,92 & 11,92 & 0,629 & 0,858280 \\
\hline $\begin{array}{l}\text { САучайная изменчи- } \\
\text { вость }\end{array}$ & 29 & 18,97 & 18,97 & & \\
\hline Всего & 59 & 580,02 & & & \\
\hline
\end{tabular}

щественно отмичацись Аруг от Аруга по симе Аействия. Аостоверным оказацось вцияние взаимодействия стиму-

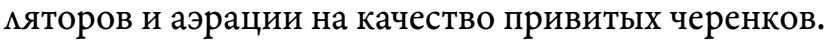

Общая корреляция многофакторной модели Аля выхода привитых саженцев достоверна и состав яет 0,921 , $\mathrm{R}^{2}=0,848$. Исследование позволяет признать с вероятностью не ниже 0,95, что вАияние срока прививки и стиму$\Lambda$ яторов на выход привитых саженцев яв яется достоверным (табл. 2). Варианты срока производства прививок и стимуляторов существенно отмичались Аруг от Аруга по силе Аействия. Недостоверным оказалось вцияние аэрации и взаимодействия стимуляторов и аэрации на выход привитых саженцев.

Результаты показывают отчетливое влияние факторов срока прививки и стимуляторов на выход саженцев винограда, которое в совокупности детерминирует более 3/4 изменчивости этого показатемя (рис. 1).

Общая коррецяция многофакторной модеми Аля вы-

Таблица 3. Одномерные результаты трехфакторного дисперсионного анализа изменчивости вызревания побега в зависимости от срока прививки, аэрации и стимуляторов

Table 3. One-dimensional results of a three-factor variance analysis of shoot lignification variability subject to grafting time, aeration and stimulants

\begin{tabular}{|c|c|c|c|c|c|}
\hline $\begin{array}{l}\text { Источник изменчи- } \\
\text { вости }\end{array}$ & $\begin{array}{l}\text { Степень } \\
\text { свободы }\end{array}$ & $\begin{array}{l}\text { Сумма } \\
\text { квадра- } \\
\text { тов }\end{array}$ & $\begin{array}{l}\text { СреА- } \\
\text { ний ква- } \\
\text { Арат }\end{array}$ & $-F$ & $\mathrm{P}$ \\
\hline Срок прививки & 1 & 0,74 & 0,74 & 0,123 & 0,728618 \\
\hline Стимукяторы & 5 & 192,70 & 38,54 & 6,371 & 0,000417 \\
\hline Аэрация & 4 & 249,24 & 62,31 & 10,300 & 0,000026 \\
\hline $\begin{array}{l}\text { Взаимодействие сти- } \\
\text { муляторов и аэрации }\end{array}$ & 20 & 846,75 & 42,34 & 6,998 & 0,000002 \\
\hline $\begin{array}{l}\text { Случайная изменчи- } \\
\text { вость }\end{array}$ & 29 & 175,44 & 6,05 & & \\
\hline Всего & 59 & 1488,44 & & & \\
\hline
\end{tabular}

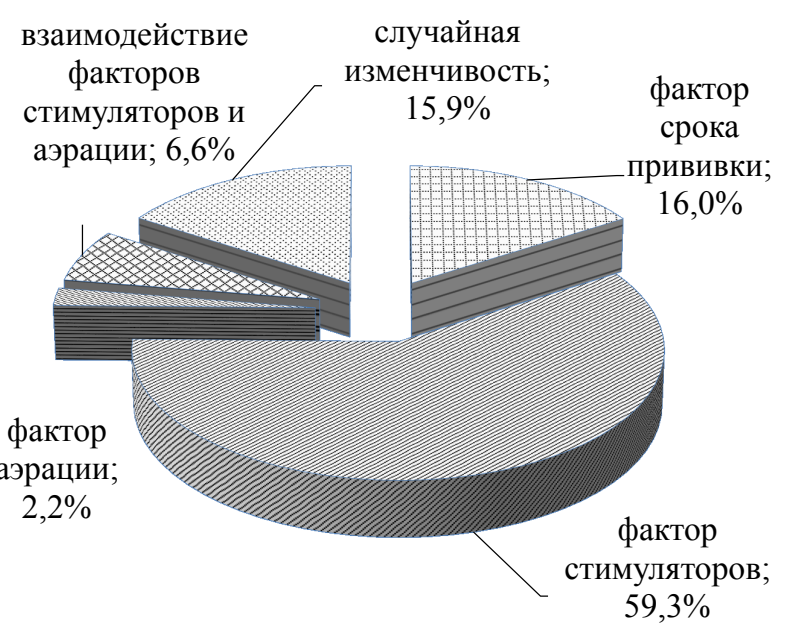

Рис. 1. Влияние срока производства прививок, длительности аэрации при стратификации «на воде» и стимуляторов роста на выход саженцев винограда

Fig. 1. The impact of the grafting time, duration of aeration during "in water" stratification and growth stimulants on the output of grapevine seedlings

зревания побега достоверна и составцяет $0,939, \mathrm{R}^{2}$ $=0,882$. Исследование позволяет признать с вероятностью не ниже 0,95, что вцияние стимуцяторов и аэрации, так же, как и их взаимодействия, на вызревание побега является достоверным (табл. 3). Варианты стимуляторов, как и варианты аэрации, существенно отличались Аруг от Аруга по симе Аействия. Недостоверным оказалось вАияние срока производства прививок на вызревание побега.

Результаты показывают значительное влияние факторов стимуляторов и аэрации, и особенно взаимодействия стимуляторов и аэрации на вызревание побега, которые в совокупности детерминируют $86,5 \%$ изменчивости этого показателя (рис. 2).

Общая корреляция многофакторной моде-

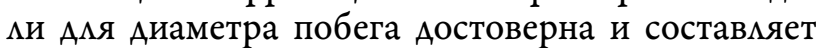
$0,860, \mathrm{R}^{2}=0,74$. Иссмедование позвомяет признать

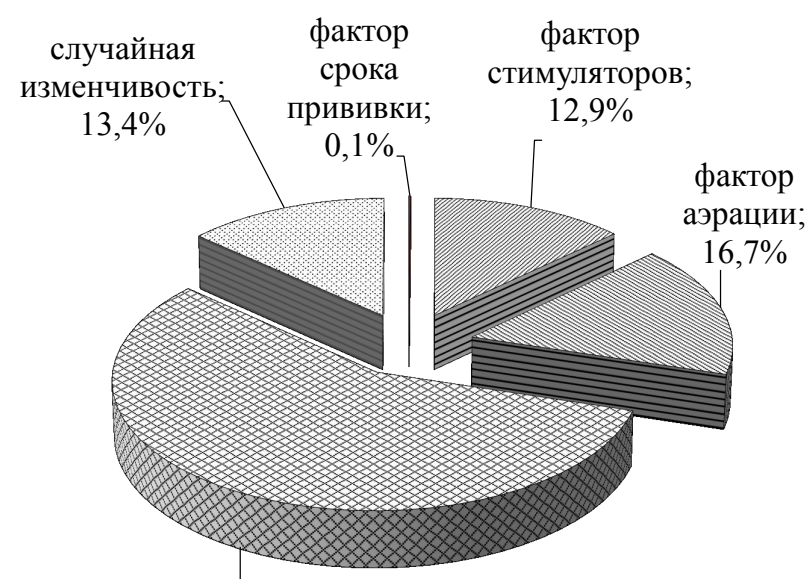

взаимодействие факторов стимуляторов и аэрации; $56,9 \%$

Рис. 2. Влияние срока производства прививок, длительности аэрации при стратификации «на воде» и стимуляторов роста на вызревание побега винограда

Fig. 2. The impact of the grafting time, duration of aeration during "in water" stratification and growth stimulants on grapevine shoot lignification 
Таблица 4. Одномерные результаты трехфакторного дисперсионного анализа изменчивости диаметр побега в зависимости от срока прививки, аэрации и стимуляторов

Table 4. One-dimensional results of a three-factor variance analysis of shoot diameter variability depending on grafting time, aeration and stimulants

\begin{tabular}{|c|c|c|c|c|c|}
\hline $\begin{array}{l}\text { Источник } \\
\text { изменчивости }\end{array}$ & $\begin{array}{l}\text { Сте- } \\
\text { пень } \\
\text { свобо- } \\
\text { Аы }\end{array}$ & $\begin{array}{l}\text { Сумма } \\
- \text { квадратов }\end{array}$ & $\begin{array}{l}\text { Срен- } \\
\text { ний } \\
\text { квадрат }\end{array}$ & $\mathrm{F}$ & P \\
\hline Срок прививки & 1 & 4,4734 & 4,4734 & 3,0363 & 0,092021 \\
\hline Стимуляторы & 5 & 23,2259 & 4,6452 & 3,1528 & 0,021536 \\
\hline Аэрация & 4 & 15,1771 & 3,7943 & 2,5753 & 0,058503 \\
\hline $\begin{array}{l}\text { Взаимодействие стиму- } \\
\text { Аяторов и аэрации }\end{array}$ & 20 & 76,1622 & 3,8081 & 2,5847 & 0,009741 \\
\hline $\begin{array}{l}\text { Случайная изменчи- } \\
\text { вость }\end{array}$ & 29 & 42,7266 & 1,4733 & & \\
\hline Всего & 59 & 164,2860 & & & \\
\hline
\end{tabular}

с вероятностью не ниже 0,95, что влияние стимуляторов, так же, как и взаимодействия стимуляторов и аэрации, на толщину побега явцяется достоверным (табл. 4). Варианты стимуляторов существенно отмичались Аруг от Аруга по симе Аействия. Недостоверным оказалось влияние срока производства прививок и аэрации на толщину побега.

Результаты показывают существенное вцияние фактора стимуляторов и взаимодействия стимуляторов и аэрации на Аиаметр побега у основания, которые в совокупности Аетерминируют 60,5 \% изменчивости этого показатемя (рис. 3).

Общая корремяция многофакторной модеми Аля ко-

Таблица 5. Одномерные результаты трехфакторного дисперсионного анализа изменчивости количества пяточных корней в зависимости от срока прививки, аэрации и стимуляторов

Table 5. One-dimensional results of a three-factor variance analysis of base roots number variability depending on grafting time, aeration and stimulants

\begin{tabular}{|c|c|c|c|c|c|}
\hline $\begin{array}{l}\text { Источник изменчи- } \\
\text { вости }\end{array}$ & $\begin{array}{l}\text { Степень } \\
\text { свободы }\end{array}$ & $\begin{array}{l}\text { Сумма } \\
\text { квадра- } \\
\text { тов }\end{array}$ & $\begin{array}{l}\text { Срен- } \\
\text { ний } \\
\text { квадрат }\end{array}$ & $\mathrm{F}$ & P \\
\hline Срок прививки & 1 & 0,6205 & 0,6205 & 29,930 & 0,000007 \\
\hline Стимукяторы & 5 & 21,5403 & 4,3081 & 207,809 & 0,000000 \\
\hline Аэрация & 4 & 3,4394 & 0,8598 & 41,477 & 0,000000 \\
\hline $\begin{array}{l}\text { Взаимодействие сти- } \\
\text { муляторов и аэрации }\end{array}$ & 20 & 15,9995 & 0,8000 & 38,589 & 0,000000 \\
\hline $\begin{array}{l}\text { Случайная изменчи- } \\
\text { вость }\end{array}$ & 29 & 0,6012 & 0,0207 & & \\
\hline Всего & 59 & 42,6373 & & & \\
\hline
\end{tabular}

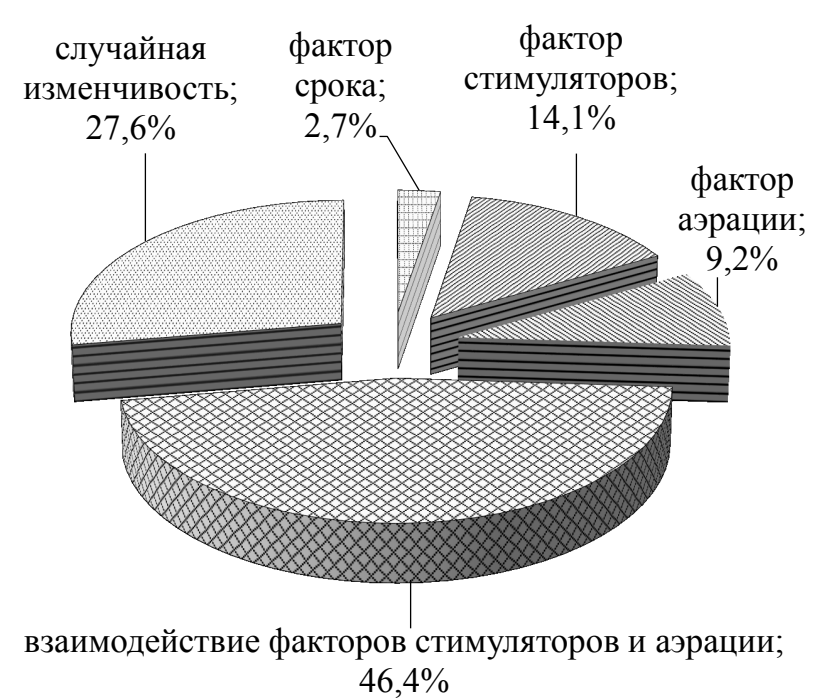

Рис. 3. Влияние срока производства прививок, длительности аэрации при стратификации «на воде» и стимуляторов роста на диаметр побега винограда

Fig. 3 The impact of the grafting time, aeration duration during "in water" stratification and growth stimulants on grapevine shoot diameter

Аичества пяточных корней достоверна и состав яет $0,993, \mathrm{R}^{2}=0,986$. Исследование позвомяет признать с вероятностью не ниже 0,95, что влияние срока производства прививок, стимумяторов, аэрации так же, как и взаимодействия стимуляторов и аэрации, на комичество пяточных корней явцяется Аостоверным (табц. 5). Варианты всех трех факторов существенно отмичались Аруг от Аруга по силе Аействия.

Результаты показывают значительное вмияние всех изучаемых факторов, а также взаимодействия стимуляторов и аэрации на количество пяточных корней, которые в совокупности Аетерминируют почти всю изменчивость этого показатеця (рис. 4).

Применение биостимуляторов следует рас-

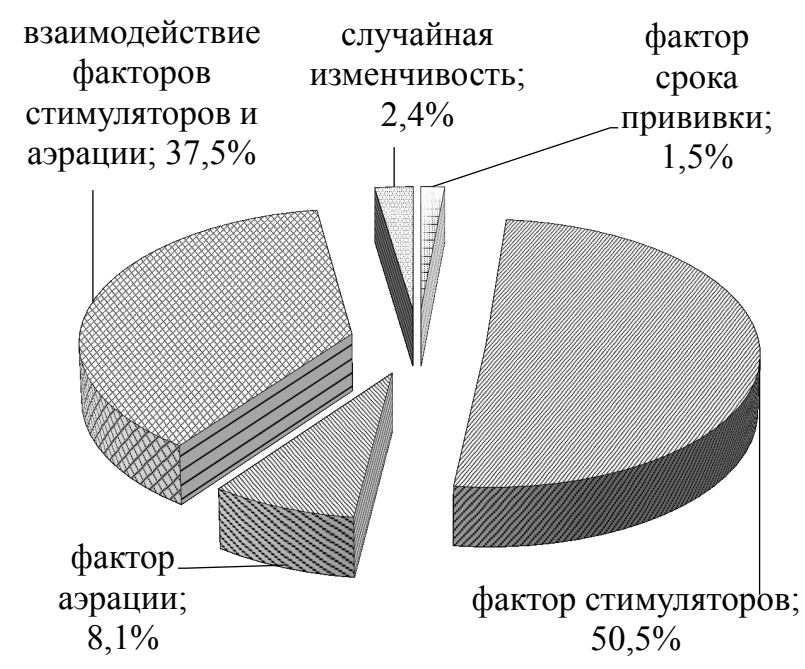

Рис. 4. Влияние срока производства прививок, длительности аэрации при стратификации «на воде» и стимуляторов роста на количество пяточных корней у саженцев винограда

Fig. 4. The impact of the grafting time, duration of aeration during "in water" stratification and growth stimulants on the number of base roots of grapevine seedlings 
Impact assessment of the grafting time, duration of aeration and growth stimulants on the output and quality of grafted...

сматривать как оАин из важных эмементов техномогии на пути совершенствования процесса стратификации черенкового материаца «на воде». Сами стимуляторы роста могут ускорить процесс образования корней, это следует считать ценным технологическим приемом, особенно в позАних сроках прививки. Применение новых физиологически активных веществ с комплексом ценных свойств, в том числе антигрибковыми и антивирусными Аействиями, будет способствовать не только повышению выхода привитых саженцев винограда, но и получению оздоровленного посаАочного материаца.

Выводы. Таким образом, влияние срока производства прививок, Алительности аэрации и стимумяторов на качество привитых саженцев винограАа явцяется Аостоверным.

\section{Источники финансирования}

Статья подготовцена в рамках выполнения Госзадания № 0833-2015-0006.

\section{Financing source}

The article was written within the framework of the State assignment № 0833-2015-0006.

\section{Конфликт интересов \\ Не заявцен.}

\section{Conflict of interests} Not declared.

\section{Список литературы / References}

1. Драновский В.А. Улучшение технологии хранения привитых виноградных саженцев/ В.А. Драновский, Н.А. Карагуц, Л.А. Чекмарев, Т.О. Ливчак, В.А. Банный // Пути решения продовольственной программы в виноградарстве. - 1985. - T. XXII. - C.82-94.

Dranovsky V.A. Technological improvement of grafted grapevine plants storage / V.A. Dranovsky, N.F. Karaguts, L.A. Chekmarev, T.O. Livchak, V.A. Banny // Addressing the food program in viticulture. - 1985. - V. XXII. - P.82-94. (in Russian)

2. Терещенко А.П. Производство привитого посадочного материала винограда. -Симферополь: Таврия, 1992. - 102 с.

Tereshchenko A.P. Production of grafted planting material of grapevines. - Simferopol: Tavria, 1992. - 102 p. (in Russian)

3. Клименко В.П. Пасынкование у подвоев винограда / В.П. Клименко, М.Н. Борисенко, Н.Л. Студенникова, А.И. Рачинская, О.В. Разгонова, 3.В. Котоловець, С.Г. Макеев, В.А. Володин // «Магарач». Виноградарство и виноделие. - 2013. - № 1. - C. 3-4.

Klimenko V.P. Lateral shoots removal in grapevine rootstocks / V.P. Klimenko, M.N. Borisenko, N.L. Studennikova, A.I. Rachinska, O.V. Razgonova, Z.V. Kotolovets, S.G. Makeiev, V.O. Volodin // "Magarach". Viticulture and Winemaking. - 2013. № 1. - pp. 3-4. (in Russian)

4. Клименко В.П. Качество прививки на новых подвойных сортах винограда / В.П. Клименко, М.М. Борисенко, Н.Л. Студенникова, А.И. Рачинская, О.В. Разгонова, 3.В. Котоловець, С.Г. Макеев, В.А. Володин // «Магарач». Виноградарство и виноделие. - 2013, - № 3. - С. 2-3.

Klimenko V.P. The quality of grafting on new rootstock grapevine cultivars // V.P. Klimenko, M.N. Borisenko, N.L. Studennikova, A.I. Rachinska, O.V. Razgonova, Z.V. Kotolovets, S.G. Makeiev, V.O. Volodin // "Magarach". Viticulture and Winemaking. -
2013. - № 3. - pp. 2-3. (in Russian)

5. Corso M. Grapevine rootstock effects on abiotic stress tolerance / M. Corso, C. Bonghi // Plant Sci. Today. - 2014. - № 1. - P. 108-113.

6. Manzi M. Root ABA accumulation in long-term water-stressed plants is sustained by hormone transport from aerial organs / M. Manzi, J. Lado, M. J. Rodrigo, L. Zacarhas, V. Arbona, A. Gymez-Cadenas // Plant Cell Physiol. - 2015. - V. 56. - P. 2457-2466.

7. Marguerit E. Rootstock control of scion transpiration and its acclimation to water deficit are controlled by different genes / E. Marguerit, $\mathrm{O}$. Brendel, E. Lebon, C. Van Leeuwen, N. Ollat // New Phytol. - 2012. V. 194. - P. 416-429.

8. Tramontini S.A. Rootstock control of scion response to water stress in grapevine / S. Tramontini, M. Vitali, L. Centioni, A. Schubert // Environ. Exp. Bot. - 2013. - V. 93. - P. 20-26.

9. Waite H. Grapevine propagation: principles and methods for the production of high-quality grapevine planting material / $\mathrm{H}$. Waite, M. Whitelaw-Weckert, P. Torley // New Zealand Journal of Crop and Horticultural Science. - 2015. - V. 43, № 2. - pp. 144-161.

10. Hartmann H.T. Hartmann and Kester's plant propagation: principles and practices / H.T. Hartmann, D.E. Kester, F.E. Davies, R. Geneve. Englewood Cliffs, New Jersey: Prentice-Hall, 8th edition. - 2001. - 928 p.

11. Mullins M.G. Biology of the grapevine / M.G. Mullins, A. Bouquet, L.E. Williams. Great Britain: Cambridge University Press, 1992. - 239 p.

12. Warschefsky E. Rootstocks: diversity, domestication, and impacts on shoot phenotypes / E. Warschefsky, L. L. Klein, M. H. Frank et al. // Trends Plant Sci. - 2016. - V. 21. - pp. 418-437.

13. Замета О.Г. Сравнительная характеристика стимуляторов корнеобразования Гумисол и Риверм при производстве привитых вегетирующих саженцев винограда / О.Г. Замета, М.Н. Борисенко, В.А. Володин // «Магарач». Виноградарство и виноделие. - 2012. - №1. - C.11-12.

Zameta O.G. Comparative characteristics of rooting stimulants Humisol and Riverm in the production of grafted vegetative grapevine seedlings / O.G. Zameta, M.N. Borisenko, V.O. Volodin // "Magarach". Viticulture and Winemaking. - 2012. - № 1. - pp. 11-12. (in Russian)

14. Шерер В.О. Применение регуляторов роста в виноградарстве и питомниководстве / В.О. Шерер, Р.Ш. Гадиев. - Киев: Урожай, 1991. - 112 c

Scherer V.O. Application of growth regulators in viticulture and nursery / V.O. Scherer, R.Sh. Gadiev. - Kiev: Urozhai, 1991. - 112 p. (in Russian)

15. Aloni B. Hormonal signaling in rootstock-scion interactions / B. Aloni, R. Cohen, L. Karni, H. Aktas, M. Edelstein // Scientia Horticulturae. 2010. - V. 127, № 2. - P. 119-126.

16. Pearse H.L. The effect of nutrition and phytohormones on the rooting of vine cuttings // Annals of Botany. 1943. - V. 17. - P. 123-132.

17. Köse C. Effects of some plant growth promoting rhizobacteria (PGPR) on graft union of grapevine / C. Kose, M. Guleryiiz, F. Şahin, I. Demirtaş // Journal of Sustainable Agriculture. - 2005. - V. 26, № 2. - P. 139-147.

18. Köse C. Effects of auxins and cytokinins on graft union of grapevine (Vitis vinifera)/ C. Köse, M. Güleryüz // New Zealand Journal of Crop and Horticultural Science. 2006. - V. 34, № 2. - P. 145-150.

19. Shirani Bidabadi S. Iranian Grapevine Rootstocks and Hormonal Effects on Graft Union, Growth and Antioxidant Responses of Asgari Seedless Grape / S. Shirani Bidabadi, M. Afazel, P. Sabbatini // Horticultural Plant Journal. - 2018. - V. 4, № 1. - P. 16-23.

20. Дерендовская А.И. Влияние обработки черенков подвоя гетероауксином на рост растений в школке, выход и качество саженцев винограда / А.И. Дерендовская, Е.А. Морошан // Биология вино- 
града и разработка элементов прогрессивных технологий его размножения и возделывания. - Кишинев: 1988. - С. 27-32.

Derendovskaya A.I. Effect of stock cuttings treatment with heteroauxin on plant growth in nursery, yield and quality of grapevine plants / A.I. Derendovskaya, E.A. Moroshan // Grapevine biology and the development of progressive technology elements of its reproduction and cultivation. - Kishinev: 1988. - P. 27-32. (in Russian)

21. Майстренко Л.А. Использование регуляторов роста в производстве посадочного материала / Л.А. Майстренко // Перспективы производства привитого посадочного материала винограда. - Новочеркасск, 2001. - С. 40-46.

Maystrenko L.A. The use of growth regulators in the production of planting material / L.A. Maystrenko // Prospects for the production of grafted planting material of grapevines. - Novocherkassk, 2001. - P. 40-46. (in Russian)

22. Малтабар Л.М. Влияние регуляторов роста на регенерационные свойства черенков винограда / Л.М. Малтабар, А.А. Гугучкин, Е.Н. Котова, И.М. Панкин // Виноградарство и виноделие. -2002 . - № 2. - C. 36-38.

Maltabar L.M. The impact of growth regulators on the regenerative properties of grapevine cuttings / L.M. Maltabar, A.A. Guguchkin, E.N. Kotova, I.M. Pankin // Viticulture and Winemaking. - 2002. № 2. - pp. 36-38. (in Russian)
23. Радчевский П.П. Влияние биологически активных веществ на регенерационные свойства виноградных черенков, выход и качество саженцев. - Краснодар: КубГАУ, 2017. - 274 с.

Radchevsky P.P. The impact of biologically active substances on the regenerative properties of grapevine cuttings, vine yield and quality. - Krasnodar: KubSAU, 2017. - 274 p. (in Russian)

24. Борисенко M.Н. Малозатратный способ защиты места прививки у привитых черенков винограда при стратификации «на воде» / М.Н. Борисенко, В.А. Радченко // «Магарач». Виноградарство и виноделие. - 2006. - № 4. - С.15-16.

Borisenko M.N. Low-cost method of protecting the site of grafting in grafted cuttings of grapes with stratification «on the water» / M.N. Borisenko, V.A. Radchenko // "Magarach". Viticulture and Winemaking. - 2006. - № 4. - pp. 15-16. (in Russian)

25. Волынкин В.А. Оптимизация биотехнологии оздоровления посадочного материала и ускоренного размножения перспективных сортов винограда / В.А. Волынкин, В.П. Клименко, И.А. Павлова, В.А. Зленко // «Магарач». Виноградарство и виноделие. -2011 . - № 4. - С. 31.

Volynkin V.A. Biotechnology optimization for planting material revitalization and accelerated reproduction of promising grapevine cultivars / V.A. Volynkin, V.P. Klimenko, I.A. Pavlova, V.A. Zlenko // "Magarach". Viticulture and Winemaking. - 2011. - № 4. - P. 31. (in Russian) 